European journal of American studies

\title{
"I Am Your Faggot Anti-Pope": An Exploration of Marilyn Manson as a Transgressive Artist
}

\section{Coco d'Hont}

\section{(2) OpenEdition}

\section{Journals}

Electronic version

URL: https://journals.openedition.org/ejas/12098

DOI: $10.4000 /$ ejas. 12098

ISSN: 1991-9336

Publisher

European Association for American Studies

Electronic reference

Coco d'Hont, "'I Am Your Faggot Anti-Pope": An Exploration of Marilyn Manson as a Transgressive Artist", European journal of American studies [Online], 12-2 | 2017, document 14, Online since 01 August 2017, connection on 08 July 2021. URL: http://journals.openedition.org/ejas/12098 ; DOI: https:// doi.org/10.4000/ejas.12098

This text was automatically generated on 8 July 2021.

Creative Commons License 


\title{
"I Am Your Faggot Anti-Pope": An Exploration of Marilyn Manson as a Transgressive Artist
}

\author{
Coco d'Hont
}

1 "As a performer," Marilyn Manson announced in his autobiography, "I wanted to be the loudest, most persistent alarm clock I could be, because there didn't seem to be any other way to snap society out of its Christianity- and media-induced coma" (Long Hard

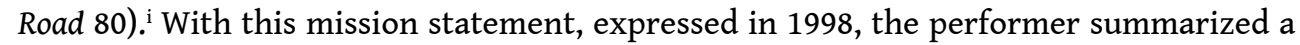
career characterized by harsh-sounding music, disturbing visuals, and increasingly controversial live performances. At first sight, the red thread running through the albums he released during the 1990s is a harsh attack on American ideologies. On his debut album Portrait of an American Family (1994), for example, Manson criticizes ideological constructs such as the nuclear family, arguing that the concept is often used to justify violent pro-life activism. ii Proclaiming that "I got my lunchbox and I'm armed real well" and that "next motherfucker's gonna get my metal," he presents himself as a personification of teenage angst determined to destroy his bullies, be they unfriendly classmates or the American government. Later album Antichrist Superstar (1997) has a more ambitious scope and cemented Manson's status as what he calls "the Antichrist Superstar," an anti-social character representing everything mainstream America supposedly rejects. Antichrist Superstar is packed with religious metaphors and references to celebrity culture, narrating Manson's metamorphosis from "the boy that you loved" into "the man that you fear." The album defines Manson as an Antichrist Superstar who functions, the artist has argued, as an antidote to authoritative oppression and hypocrisy.

2 Needless to say, this defiant attitude has attracted frequent backlashes over the years. Particularly during the late 1990s Manson's notoriety, popularity, and media exposure climaxed. For this reason, this article focuses predominantly on the albums released during this era. The complex reception history of Manson's work includes an infamous statement made by Senator Joseph Lieberman, who called Manson's band "perhaps the 
sickest group even promoted by a mainstream record company" (Bowling) in 1997. During the same period protesters, many of them affiliated with the Christian Right, campaigned for his performances to be banned, with occasional success. The criticism addressed to Manson reached its peak after the Columbine High School massacre in 1999, during which two supposed fans of the band killed twelve fellow students and a teacher. Michael Moore's documentary Bowling for Columbine, though not focusing on Manson alone, narrates how the artist was turned into a scapegoat by politicians and activists such as Lieberman, despite evidence that the killers were not actually fans of Manson. ${ }^{\text {iii }}$ Rather than toning down his message or live performances, Manson responded by increasing the amount of sex, drugs and rock 'n roll-type behavior in his live performances. During the late 1990s, Manson shows frequently featured partial nudity, simulated sexual interactions between band members and occasionally audience members, profanity, and the violent destruction of the band's own equipment. As a result, Manson and his band became synonymous with violence, political incorrectness, and on- and off-stage destruction.

With this controversy in mind, it seems appropriate to read Manson's work and its reception through the critical lens of transgression in order to interrogate its reliance on a range of boundary crossings including, but not limited to, its emphasis on antisocial opinions and behavior. However, existing uses of transgression as a critical term in a musical context are not straightforwardly applicable to Manson, due to the complicated position he occupies within the pop-cultural landscape of the 1990s. While he played metal festivals such as Ozzfest and Dynamo Open Air during this period, his work also betrays strong influences of pop, industrial, and glam rock. His 1998 album Mechanical Animals is a particularly strong example of his musical hybridity: it maintains the profanity and violent themes of its predecessors, buts adopts a popinspired sound and brightly-colored visuals. This artistic fluidity suggests that existing critical uses of transgression such as Keith Kahn-Harris's, who describes extreme metal as transgressive because it is "excessive, testing and breaking boundaries, invoking the joys and terrors of formless oblivion" (30) are not entirely applicable to Manson and his work. While Manson's 1990s albums and performances attracted significant levels of controversy, he did not share the radical sound or underground values of extreme metal bands such as Mayhem or Burzum. Musically and socially speaking, Manson actively maintained strong connections with the mainstream: he frequently appeared on talk shows, had a productive relationship with MTV, and played festivals with a strong "pop" focus, such as Pink Pop. Reading his work through a definition of transgression inspired by extreme metal is therefore problematic, and risks overlooking his intimate connections with the pop-cultural mainstream.

This evokes the question to what extent transgression, when used to read Manson, should be defined as a synonym for the breaking of taboos and the definite move beyond social and moral limits. Readings of extreme metal using the term frequently suggest that transgression occurs from a position outside or in opposition to civilization, breaking taboos and crossing lines to the point of no return. Hjelm et al., for example, define the transgressiveness of extreme metal as "the practice of boundary crossing, symbolically and/or practically, the practice of questioning and breaking taboos, the practice of questioning established values" (10). For Karen BettezHalnon, transgressive extreme metal performers are "challenging nearly every conceivable social rule governing taste, authority, morality, propriety, the sacred, and, some might say, civility itself" (34). This definition may apply to extreme metal 
musicians such as Varg Vikernes or Gaahl, iv but is too radical to adequately capture the position of Manson within American pop culture. In many of his songs, writings and interviews Manson has positioned himself as an "all-American" artist who, despite frequently veering beyond the limits of American society, maintains strong connections with that society. Mechanical Animals, for example, displays a strong fascination for celebrity culture and fame, and the video for "Coma White" shows Manson getting shot in a way which resembles the murder of John F. Kennedy. No matter how strong his attacks on American ideologies, and no matter how much controversy they generated, Manson exists in relation to, rather than in opposition to, civilization, society, and the cultural mainstream.

Contesting the conceptualization of Manson as an artist who exists in opposition to society and mainstream culture also problematizes the connection between transgression and the involvement in a more or less clearly defined radical political project. Many readings of extreme metal and less extreme genres, such as rock, suggest that performers and their fans can act as questioners and disturbers of generally accepted norms and ideas, and therefore have some form of political power. ${ }^{v}$ Manson's "political activism," on the other hand, barely moves beyond the level of rhetoric and as such contrasts sharply with more explicitly political musical movements of the 1990s, such as Riot Grrrl. Much of the notoriety Manson gained during the 1990s arose from his aggressive stance towards various forms of authority, including organized religion, the American government, and the patriarchal nuclear family. Lyrics such as those of "The Beautiful People," a song which proclaims that "capitalism has made it this way / old-fashioned fascism will take it away," appear to be intended as a fullfrontal attack on central American ideologies. Observations such as these could cause one to interpret Manson's music and persona as an attempt to construct a powerful "anti"-voice, with the aim to disrupt and/or destroy the stability of the society kept in place by the limits he persistently crosses. However, Manson did not translate his verbal attack on American ideologies into concrete political actions, and his continued fascination with fame, celebrity culture, and Americana suggests that this was never truly his intention. Reading transgression as a fundamentally political process therefore runs the risk of misreading Manson's agenda and overestimating his political intentions.

These considerations call for an adapted definition of transgression which is able to capture the complexities of Manson and his work, without overplaying his political influence or overlooking his strong connections to mainstream American pop culture. In this article, I therefore use a definition of transgression which focuses on its function as a (re)constructive, rather than a predominantly destructive force. This definition of transgression as ideological (re)construction has a significant philosophical history which emphasizes how transgression, through the very act of crossing boundaries, (re)constructs social limits. Georges Bataille, for example, argues that transgression "opens the door into what lies beyond the limits usually observed, but it maintains these limits just the same" (67). He therefore concludes that "[o]rganised transgression together with the taboo makes social life what it is" (65), and is an inherent aspect of society rather than its contradiction or destruction. The crossing of moral, social and cultural boundaries, in other words, does not result in the destruction or permanent disruption of social order, but maintains and redraws the limits which keep society in place. As a result, transgression and the limit are not oppositional forces, but intimately connected like "a spiral which no simple infraction can exhaust" (Foucault 
35). While transgression can have a subversive effect, its subversive potential should be read in a social rather than an anti-social or revolutionary way. Transgression does not occur in opposition to stable, clearly defined limits, but involves the very (re)construction of those limits.

7 Applied to Manson, this theoretical framework facilitates a reading of the man and his work as a transgressive artist, not because he offers a viable alternative to mainstream American culture, or because he permanently disrupts American values, but because he facilitates the (re)construction of central American ideologies by means of crossing cultural, social and moral boundaries. Rather than under- or overstating the radical potential of Manson as a transgressive artist, this article traces how he and his work exist in interaction with, and help (re)construct, the boundaries which demarcate what "the mainstream" and "American ideologies" mean. The article explores three areas in which this (re)constructive aspect of his transgressions is most evident. I start with a reading of Manson as an "anti-hero" (Bostic et al. 54) who provides a liminal space where adolescents can successfully complete the transition into adulthood. I read Manson's music as "the reformulation of old elements into new patterns" (Turner 99), or a rite-de-passage which facilitates the transformation from child to adult. This reading considers transgression as "inwards" move aimed at "fitting in," rather than a definite move beyond social, cultural or moral boundaries. Secondly, I explore Manson's close relationship with mainstream culture and media, particularly with MTV. I show how Manson conforms to and reinvents pop culture conventions, rather than abandoning them, and argue that his controversial behavior should be situated within a long tradition of "rock 'n rage" (Wilson 4). Finally, I study Manson's adaptation of a (partially self-created) Satan persona, and demonstrate how Manson's positioning of himself as the personification of "anti-America" (re)constructs the limits of American society. While Manson's appropriation of Satan as a transgressive symbol, and his demonization by politicians and angry parents, could cause one to read Manson's "Satanism" as the ultimate attack on American values, I read it as a fluid product of sophisticated socio-cultural power play. The transgressiveness of Manson's artistry, the article concludes, is as much about (re)construction as it is about destruction.

\section{Transgression and Adolescence: Breaking Free to Fit In}

8 Even though his audience is by no means limited to adolescents, Manson's lyrics frequently explore adolescent themes, particularly on albums released during the 1990 s. $^{\text {vi }}$ His portrayal of adolescence as a transgressive time during which social and moral limits are crossed, tested and explored is hardly new, and can be traced all the way back to 1950s musicians such as Elvis Presley. At first sight, drawing connections between Manson and Presley may seem farfetched. After all, the profanity and violence which characterized Manson's shows during the 1990s are a far cry from Presley's comparatively innocuous hip movements. However, Manson has frequently mentioned Elvis Presley as an important musical influence, has described himself as someone who "just sings some rock 'n roll songs," vii and has covered Elvis's song "In the Ghetto." While his music, persona and visuals are very different from those created by Elvis, Manson's early work explicitly and persistently addresses adolescent themes. Music 
videos such as "Lunch Box" (1995) communicate a strong sense of teenage angst, with the singer addressing bullying and alienation, promoting metal lunchboxes as weapons to combat unspecified "motherfuckers." The video alternates images of the singer and his band performing in a roller skating rink with shots of a young boy shaving his head and confronting his bullies. The song suggests a form of empowerment, inviting its listeners to stand up to the forces limiting them, and using whatever means necessary to establish their freedom. While the song's message and its visual accompaniment are much more aggressive than Elvis's renditions of "Hound Dog" or "Jailhouse Rock," Manson's music provides similar opportunities for boundary crossing to the adolescents in his audience. He even incorporates prominent hip vibrations into the "Lunch Box" video, although it would be farfetched to interpret this as a deliberate nod to Elvis.

9 At the end of the day, however, the song's conclusion that the singer desires to "grow up" suggests that, for Manson, adolescence is a temporary state of transition and transformation, rather than a permanent attempt to move beyond the limits of society. As a result, Manson's music functions as a liminal space where adolescents can (re)form their identities away from social constraints, in order to rejoin the mainstream as

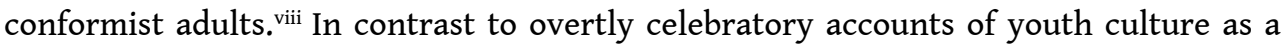
space for social resistance and transformation, ${ }^{\text {ix }}$ Manson's work can be more accurately understood from the perspective of sociological theories which emerged at the same time as his early albums, and which claim that subcultural expression "is not a challenge to the system, but a liberal declaration of freedom of expression" (Muggleton 149). ${ }^{x}$ In "Lunch Box" Manson expresses the desire to "be a big rock and roll star," suggesting that his rebellion is part of a cyclical process not aimed at a permanent move beyond social limits, but envisioned more as a complex process of boundary negotiation with the aim of achieving a position of social prominence and celebrity. To a certain extent, Manson enables his young fans to temporarily escape from the boundaries imposed on them by their parents, teachers, and other authority figures. In a much more extreme version of Elvis' notorious performance at the $E d$ Sullivan Show, his performances are spaces where the audience can move virtually unrestricted. Live music videos, such as the one for "Antichrist Superstar" (1998), show excited fans pumping their fists in the air and chanting along to a song with fascist undertones. The shows and music perform a function as carnivalesque safety valves, where anti-social behavior can be explored, and identity and emotions can be freely expressed. However, apart from provoking outraged responses from parents, politicians and other authority figures, Manson's music and persona have not notably altered the American socio-political landscape, and it is questionable whether generating political change was even his intention in the first place. ${ }^{\mathrm{xi}}$ While his lyrics frequently conceptualize adolescence as a liminal period of confusion and boundary negotiation, they suggest that it leads towards a form of "fitting in," or more precisely, acquiring a position of power within the adult world.

10 Far from suggesting that this limited political effect of his artistic endeavors is accidental, the music Manson released during the 1990s indicates that mainstream absorption was his goal all along. He actively developed the transition to adulthood into a metaphor for his own transgression from underground into mainstream, using images of growth and evolution to communicate his aspirations as an artist. In addition to functioning as an "anti-hero" (Bostic et al 54) who guides adolescents towards 
adulthood, Manson also uses his accounts of this transition to carve out a position within mainstream culture for himself. After Portrait of an American Family (1994), a record dominated by social angst and anti-authoritarian ideas, Manson released Antichrist Superstar (1997), a concept album which narrates his transformation from "the boy that you loved" into "the man that you fear" ("Man that You Fear"). The different forms of "anti" described in the song "1996," ranging from "anti-pope" to "anti-Satan," initially appear be a call for the abandonment of all existing forms of authority. However, Manson's transgressiveness is ultimately a move towards the mainstream and the grown-up. Antichrist Superstar is packed with organic metaphors and features extensive imagery of worms transforming into butterflies, children growing up to become adults, and seedlings developing into weeds. This sense of growth and development is further enforced by the publication of Manson's autobiography The Long Hard Road Out of Hell, a partially fictionalized memoir which traces his development from a typical suburban child into a notorious rock star. . $^{\text {xii }}$ Towards the end of Antichrist Superstar Manson declares that "we're on the other side now" and that the "wormboy" has transformed into "Mr Superstar." Similarly, The Long Hard Road Out of Hell concludes that "I feel like we've grown in the past year, and I'm glad that its over" (269). Even though Manson's work describes adolescence as a period of rebelliousness, it ultimately results in the construction of an adult persona rather than a definitive move away from the constraints of the mainstream. Later Manson albums, such as Mechanical Animals (1998), suggest that this development was not merely a matter of "growing older and wiser," but part of a sophisticated attempt to reconstruct the rock star and assume a position of power in the centre of American pop culture.

\section{Reinventing the Rock Star. From Underground to MTV}

In his 1998 autobiography, Manson provocatively stated that he aimed to become "bigger than Kiss" (153). With this statement he confirmed that his transgressions of moral, social and cultural boundaries during the 1990s were ultimately supposed to help him fit in with mainstream culture, rather than provoking this culture's radical transformation or abolishment. After Antichrist Superstar, with its explicit attacks on Christianity and its flirtations with fascism, complemented by horror-inspired visuals, Manson reinvented himself again with the release of Mechanical Animals (1998), an album which firmly situated him within mainstream pop culture. While the record maintains many of the shocking elements that characterized Manson's earlier work, particularly its explicit references to drugs and sex, it frames these elements as a reinvention of pop conventions rather than as criticisms of authority. Songs such as "The Dope Show" and "I Don't Like the Drugs (But the Drugs Like Me)" communicate a strong sense of indulgence, decadence and hedonism. Contrary to Antichrist Superstar, which superficially appeared to frame this type of behavior as an assault on mainstream American ideologies, Mechanical Animals portrays it as part of a popcultural tradition. Both musically and stylistically, Mechanical Animals betrays a strong influence of 1970s glam rock, particularly its use of science fiction themes (Lenig 14). The concept which loosely ties the songs together revolves around Manson's alter ego Omega, an alien who embarks on an ill-fated quest to become a successful rock star. 
Both this theme and Manson's transformed appearance-pale face, bright red hair, platform boots and shiny suits-invoke strong connections with David Bowie's Ziggy Stardust, and appear to reinvent an iconic part of pop music history. Rather than presenting his image as truly "new," Manson tapped into a familiar pop convention and reinvented himself as the archetypical "rock star." His actions and appearance were therefore not intended to be underground or anti-mainstream; they were exactly what could be expected of a rock star of his stature.

Manson's continuing exploration of controversial subjects, paired with the adaptation of a more pop-influenced sound and ever-increasing interactions with the media, allowed him to cross over from underground to mainstream during the Mechanical Animals-era. His negotiation of this boundary builds from, and takes further, a long tradition of shock rock, defined by Leslie M. Meier as a genre created by musicians who "use violent imagery, grotesque costumes, or disturbing antics to make the audience feel uncomfortable, or to 'gross them out"' (250). Manson's attacks on parents and other authority figures echo the work of earlier bands, such as Twisted Sister ("We're Not Gonna Take It"), Motley Crüe ("Smokin' in the Boy's Room), and Alice Cooper ("School's Out"), who all praise and promote disobedience and rebellious behavior. Manson has never shied away from the profanity, violence and eroticism which characterizes the work of most shock rockers, covering Screamin' Jay Hawkins' "I Put a Spell on You" in 1995, and including a sample from Arthur Brown's "Fire" in his 1997 song "Lunch Box." Mechanical Animals took these experimentations to a whole new level, by communicating controversial themes through a more accessible, popinfluenced sound, accompanied by bright and striking visuals. What makes this album truly stand out from other examples of shock rock-many of which have attracted mainstream attention and/or commercial success-is its self-reflectiveness. The album uses science fiction imagery and sex, drugs and rock 'n roll references to reflect on fame and celebrity culture, with songs such as "The Dope Show" musing that "they love you when you're on all the covers / when you're not, then they love another." Instead of merely generating controversy to attract media exposure, Mechanical Animals is a much more sophisticated project which offers a cynical analysis of the very journey towards fame it aims to facilitate.

13 Manson was by no means the first shock rocker to attract mainstream attention, but few others generated exposure on the same scale. A major reason for his evolution into a pop cultural icon during the Mechanical Animals-era was his successful alliance with one of the prime pop cultural media of the 1990s. Manson's striking music videos became a regular feature of MTV's broadcasting schedule and introduced his music and persona to a much larger audience than the one he could have reached through live shows and record sales alone. During the Mechanical Animals era in particular, MTV facilitated Manson's transgression from underground artist into the cultural realm where rock stars function as capitalist commodities. The music video for "Rock Is Dead" reflects this transformation: it is a fairly conventional rock video which shows Manson and his band performing on stage, destroying their equipment at the end. However, Manson took his interpretation of music video conventions far beyond this point, adapting the genre which E. Ann Kaplan classifies as the "nihilist" music video, "the paradoxical linking of an overall vitality... with a nihilistic ideology" (60). Music videos such as "The Dope Show" and "I Don't Like the Drugs (But the Drugs Like Me)" exaggerate the "unstable, alien" world and androgyny that Kaplan regards as 
fundamental to nihilist music videos. In both videos Manson transforms into an alien with breasts and no genitals, and in "The Dope Show" he eventually triumphs as a rock star, performing to an overexcited audience of teenagers and police officers. The evolution of Manson's music videos during the Mechanical Animals-era documents, intentionally or not, how Manson crossed over into the mainstream and blended pop conventions with shock rock themes.

However, the cynicism found in lyrics such as "we're all stars now in the dope show" ("I Don't Like the Drugs") forecasted the complexities of Manson's rise to fame. During the late 1990s Manson generated an unprecedented amount of media exposure: he was the subject of a special episode of MTV's Total Request Live dedicated to him and his work, saw the Mechanical Animals cover displayed on a Times Square billboard, and appeared on Late Night With David Letterman, The Howard Stern Radio Show, and many other talk shows. Manson's transgression of the underground-media boundary highlighted the fluid and constantly changing nature of pop culture, as well as the capitalist dynamics underlying celebrity culture. Through the success of Mechanical Animals and the accompanying publicity-the album sold over 1.5 million copiesManson successfully negotiated the boundary between underground subculture and pop mainstream, turning himself into a capitalist commodity and "big rock and roll star," at least for a short period. But there were tensions and conflicts, particularly with the broadcaster which had made such a significant impact on his career. In 1998 Manson criticized MTV during an appearance on The Howard Stern Show, claiming that MTV refused to show footage of transgender performer The Goddess Bunny, who joined the stage during his show at the 1998 MTV Music Awards. Soon after the Howard Stern interview Manson swallowed his criticism and continued to work with MTV, with profitable effects for all involved. Despite the "limits" enforced by the broadcaster, the Music Awards performance gained Manson significant exposure, and the case illustrates Manson's earlier point that "[i]t's always been a game of not compromising but also knowing your limits and doing the best you can within those limits" (Long Hard Road 150). For Manson, transgression is not a creative practice which ignores or destroys social limits, but a critical project which is acutely aware of their power and carefully negotiates them.

\section{Satan and Social Order: (Re)constructing America}

Manson's commercial success and mainstream exposure did not completely erase his notoriety. If anything, his absorption into pop culture made him even more controversial. His frequent appearances on talk shows, as well as the attention his performances received by mainstream media, attracted the attention of politicians, concerned parents, and the Christian Right. Given that "Christian religious feeling has by and large opposed the spirit of transgression" (Bataille 118), it is unsurprising that the reconstructive qualities of Manson's transgressions are particularly visible in his clashes with the Christian Right and in his appropriation of Satan and the Antichrist as alter egos. Particularly on Antichrist Superstar, Manson presented himself as an antiChristian figure, adding to his notoriety by publicly identifying himself as a member of Anton LaVey's Church of Satan. Not only did he tap into the fairly recent moral panic surrounding satanic ritual abuse, ${ }^{\text {xiii }}$ he also connected his persona to the long history of Satan as a figure within American culture, becoming one of the "Satans" against which 
mainstream America developed its idea of itself as "the great protector" (Wilson 4). Music videos such as the one for "Antichrist Superstar," in which Manson rips up a Bible surrounded by semi-fascist banners and uniforms, firmly position him as a "folk devil," providing "visible reminders of what we should not be" (Cohen 2). While it could be argued that Manson partially succeeded in questioning the rules and regulations of his society, it is also apparent that his controversial persona gave the Christian Right and the government he despised a clearly-defined enemy to define themselves in opposition to. Manson as "Satan" is a product developed in conversation with his society, rather than a threat with anti-social origins.

The tension between Manson and his opponents reached a climax when Manson was caught up in the Columbine High School Massacre controversy in 1999, and blamed for a school shooting. While some jumped at the opportunity to describe Manson as a dangerous attacker of American values, ${ }^{\text {xiv }}$ Columbine's aftermath also demonstrates that the supposed "threat" of Manson was a displacement of the harmful aspects of those values, including religious fundamentalism and gun culture. Superficially, the aftermath of the shooting, in which two high school students killed twelve fellow students and one teacher, appears to be a straightforward response to a tragedy, with many seeking to identify what caused Dylan Klebold and Eric Harris to commit their violent acts, and drawing firm boundaries between themselves and these violent "others." Some media were quick to connect the shooters to Marilyn Manson, even though they were not fans of the band. However, Manson himself undermined this oppositional image in his response to the massacre. In an open letter published in Rolling Stone he argued that "Christianity has given us an image of death and sexuality that we have based our culture around" (23), drawing the controversy back within the boundaries of society rather than allowing himself to be used as a marginalized "Satan." In Bowling for Columbine, Michael Moore's documentary about the massacre, he made a similar statement, pointing out that the Columbine massacre occurred during the war in former Yugoslavia, during which the United States took part in bombardments of Kosovo. Moore himself proceeded to explicitly interpret the Columbine massacre as a consequence of "American values," more specifically gun culture and insufficient gun control. Both Manson and Moore have argued that the events at Columbine were not an attack on quintessential American practices and ideologies, but caused by the social prominence of gun culture. While Manson can hardly be characterized as unbiased, and Moore is well-known for his polemic style, there is some validity in the suggestion that religion has a darker side, and that America's gun culture promotes violence to a certain extent. Rather than an unexpected attack on American values from some unspecified "outside," the Columbine massacre was closely intertwined with those values.

Columbine's aftermath demonstrates that Manson's transgressiveness lies in his (re)construction of social order rather than the creation of the conditions for its destruction. Rather than abolishing norms and values altogether, his crossings of moral and social limits call them into question, and provoke attempts to redraw them. In his response to the Columbine massacre, Manson argued that this function of transgressive art has a long history, and that he is merely one member of a large group of musicians who have been described as threats to social order. "It's comical that people are naive enough to have forgotten Elvis, Jim Morrison and Ozzy [Osbourne] so quickly" (23) he mused, placing the Columbine aftermath in the context of a historical tradition of 
blaming musicians for moral degeneration. Indeed, the controversy surrounding his persona and music came hardly a decade after the Parents Music Resource Centre (PMRC) attempted to limit access by children by music it deemed overtly sexual or violent..$^{\mathrm{xv}}$ Justifying its existence on the grounds that rock music "is partly responsible for the numerous ills that plague the United States" (Chastanger 179), the PMRC claimed to act as a guardian of American values threatened by irresponsible musicians who were poisoning youth with songs such as Judas Priest's "Eat Me Alive." However, the PMRC's limited success suggests that it did not represent the majority of the American mainstream, despite its claims to the contrary. ${ }^{\text {xvi }}$ In fact, Marie Fontenot and Chad Harriss argue that the PMRC's condemnation increased the popularity of some musicians, citing artists such as Frank Zappa as examples of musicians who have historically benefitted from being branded as a "bad influence" (571). Transgressive art is thus part of a (re)constructive process which (re)defines the boundaries of "America," rather than defending or destroying a predetermined and stable status quo. Along with a changing society, held in place by shifting boundaries, the shape and status of transgressive art and artists changes. In Manson's case, his career was affected significantly by the aftermath of the Columbine massacre: his transgressive invasion of mainstream pop culture was reversed into a process which pushed him back into the margins. While the follow-up to Mechanical Animals, Holy Wood (2000), was critically well-received, the album enjoyed less commercial success and signified the beginning of Manson's return to the underground. Holy Wood differs significantly from Mechanical Animals: the bright colors and science fiction imagery were replaced by darker photos of Manson dressed as a variety of tarot characters, including the Devil and the Hanged Man-the latter an image of a crucified Manson which also appears on the cover. The occult atmosphere continues with the album's sound, which is considerably less popinfluenced than that of its predecessor and features distorted punk guitars and samples of gun shots. The lyrics frequently reference the aftermath of Columbine, albeit in indirect ways. "The Nobodies," for example, states that "some children died the other day / we fed machines and then we prayed," and "The Fight Song" has Manson defiantly proclaiming that "I'm not a slave to a god / that doesn't exist." Contrary to Mechanical Animals, on which Manson self-consciously inhabited the rock star-persona, Holy Wood is much more concerned with the harmful connections between violence and the media, and cynically remarks that "you should have seen the ratings that day" in the chorus of "The Nobodies."

After Holy Wood, Manson's position within the American pop-cultural landscape shifted even further towards the margins. The Golden Age of Grotesque (2003), an album which combined sexually explicit lyrics with Weimar cabaret-inspired visuals, was a commercial success and still attracted significant levels of media attention. However, this was mostly due to the record's striking visual style and sexual explicitness, as well as Manson's high-profile wedding to burlesque performer Dita Von Teese. Potentially significant causes of this change are 9/11 and the subsequent War on Terror, which displaced the "Axis of Evil" from American rock stars to the Middle East. Cultural products produced by Manson himself during this period, designed to promote him and his music, inadvertently documented his declining status as a mainstream pop artist and "folk devil." The Death Parade (2002), a short documentary shot during the God, Guns and Government tour, starts as a regular music documentary, albeit one which features more nudity, profanity and violence than most. As the tour progresses, however, the documentary shows how band members fall out with each other, how 
their behavior becomes increasingly destructive, and how the tour evolves into a drugfuelled carnival. The film is a collage of short snippets of varying quality which turn time and place into fluid concepts, a stylistic choice which contributes to the sense of confusion and disorientation it conveys. The last shot shows Manson looking worryingly out of breath, supported by first aiders and assistants after a performance. The final notes of Holy Wood inadvertently become the soundtrack of artistic collapse which appears to signify the definite ending of Manson as a significant pop cultural icon. His transgressions of moral, social and cultural boundaries, a practice which brought him fame, notoriety, cultural and material capital, seemed to have lost their relevance in the society post-9/11 America had become.

\section{Postscript: A Long Hard Road Out of Hell?}

After the collapse documented in The Death Parade, Manson's musical output continued to evolve, even though it did not attract the same kind of media attention and controversy as his earlier work. The Golden Age of Grotesque was followed by Eat Me, Drink $\mathrm{Me}$ (2007) and The High End of Low (2009), on which Manson explored more personal themes. These explorations of his troubled love life were met with mixed to negative critical responses ${ }^{x v i i}$ and contrasted starkly with Manson's earlier reinventions of himself as Antichrist or alien. In some respects, follow-up albums Born Villain (2012) and The Pale Emperor (2015) signified a return to form. These records explored familiar themes such as violence and nihilism, but adapted a blues-like musical style and largely lacked the strong anti-authoritarian themes which characterized his early work. More recently, the announcement of Say10 / Heaven Upside Down, ${ }^{\text {xvii }}$ to be released in 2017, has suggested that Manson is considering a repositioning of himself as more political artist. The teaser for the new album shows him ripping pages out of a bible and ends with him standing next to a beheaded body. The fact that the video was released on November 8 , 2016, the day of the US presidential election, suggests that Manson is reinventing some of the themes he covered during the 1990s, though it remains unclear to what extent this choice will reignite the type of controversy that characterized his career during this period.

21 The focus of Say10 / Heaven Upside Down demonstrates how Manson continues to evolve as a transgressive artist. Moving away from his seemingly clear-cut "anti"-rhetoric of the 1990s, his recent work is a much more subtle, and rather confusing, conversation with contemporary pop culture. Say10 / Heaven Upside Down's release was tentatively scheduled for Valentine's Day 2017, but the date passed without a release or an update from either Manson or his publicist. The lack of information evoked a stream of angry and confused responses by fans on social media, who aggressively tried to read meaning into Manson's increasingly obscure social media posts. The silence surrounding Say10/Heaven Upside Down has inspired a range of speculations regarding the reasons for the delay, with one critic sarcastically suggesting that Manson simply forgot to release the album (Soundblab). Whatever the real reason, Manson's silence forms an interesting contrast with the outspokenness of his early career. Some suggestions as to the artistic direction of his new work could be extracted from the album teaser, in which Manson murders a Donald Trump lookalike. In a world dominated by endless multifaceted on- and offline discourse, with an American president who takes to Twitter to voice his opinions, persistent silence is perhaps the 
only way to get noticed. Whether Manson's silence is indeed part of a sophisticated artistic project, a result of complicated music industry politics, or simply a personal choice, remains to be seen. What is clear is that his transgressions have led him back to where he once started: in conversation with religion, morals and values. His Instagram post on Say10's original release date is a Biblical quote: "And that no man might buy or sell, save he that had the mark, or the name of the beast, or the number of his name" (Rev 13:17). More than two decades after the release of his debut album, the enigma that is the transgressive artist has by no means been solved.

\section{BIBLIOGRAPHY}

Bataille, Georges. Eroticism. Trans. Mary Dalwood. London: Boyars, 1987. Print.

Bettez-Hannon, Karen. "Heavy Metal Carnival and Dis-Alienation: The Politics of Grotesque Realism." Symbolic Interaction 29.1 (2006): 33-48. Print.

Bostic, Jeff Q. et al. "From Alice Cooper to Marilyn Manson: The Significance of Adolescent Antiheroes." Academic Psychiatry 27.1 (2003): 54-62. Print.

Bowling for Columbine. Dir. Michael Moore. United Artists, 2002. DVD.

Brown, Arthur. "Fire." The Crazy World of Arthur Brown. Atlantic, 1968. LP.

Chastanger, Claude. “The Parents' Music Resource Center: From Information to Censorship." Popular Music 18.2 (1999): 179-92. Print.

Cohen, Stanley. Folk Devils and Moral Panics. London: Routledge, 2002. Print.

Cooper, Alice. “School's Out." School's Out. Warner Bros, 1972. LP.

The Death Parade. Dir. Marilyn Manson. Marilyn Manson Records, 2002. DVD.

Fontenot, Maria and Chad Harriss. "Building a Better PIG: A Historical Survey of the PMRC and its Tactics." Media, Culture and Society 32.4 (2010): 565-80. Print.

Foucault, Michel. “A Preface to Transgression.” Language, Counter-Memory, Practice: Selected Essays and Interviews. Ed. Donald F. Bouchard. Trans. Donald F. Bouchard and Sherry Simon. Ithaca: Cornell UP, 1977. 29-53. Print.

Frith, Simon. The Sociology of Youth. Ormskirk: Causeway, 1984. Print.

Gracyk, Theodore. I Wanna Be Me: Rock Music and the Politics of Identity. Philadelphia: Temple UP, 2001. Print.

Hall, Stuart and Tony Jefferson, eds. Resistance Through Rituals: Youth Subcultures in Post-War Britain. London: Routledge, 2006. Print.

Hawkins, Screamin' Jay. “I Put a Spell on You.” At Home With Screamin' Jay Hawkins. Okeh, 1956. LP. Hebdige, Dick. Subculture: The Meaning of Style. 1979. London: Routledge, 1991. Print.

Hjelm, Titus, Keith Kahn-Harris and Mark LeVine, eds. "Introduction." Heavy Metal: Controversies and Countercultures. Sheffield: Equinox, 2013. 1-16. Print. 
Hodkinson, Paul. Goth: Identity, Style and Subculture. Oxford: Berg, 2002. Print.

Judas Priest. "Eat Me Alive.” Defenders of the Faith. Columbia, 1984. LP.

Kahn-Harris, Keith. Extreme Metal: Music and Culture on the Edge. Oxford: Berg, 2007. Print.

Kaplan, E. Ann. Rocking Around the Clock: Music Television, Postmodernism, and Consumer Culture.

London: Methuen, 1987. Print.

Lenig, Stuart. The Twisted Tale of Glam Rock. Santa Barbara: Praeger, 2010. Print.

Manson, Marilyn. Antichrist Superstar. Nothing/Interscope, 1997. CD.

---. Born Villain. Cooking Vinyl, 2012. CD.

---. “Columbine: Whose Fault Is It?” Rolling Stone. 24 Jun. 1999. 23. Print.

---. Eat Me, Drink Me. Interscope, 2007. CD.

---. The Golden Age of Grotesque. Nothing/Interscope, 2003. CD.

---. The High End of Low. Interscope, 2009. CD.

---. Holy Wood. Nothing/Interscope, 2000. CD.

---. Mechanical Animals. Nothing/Interscope, 1998. CD.

---. The Pale Emperor. Hell, etc., 2015. CD.

---. Portrait of an American Family. Nothing/Interscope, 1994. CD.

---. Say10 / Heaven Upside Down. Hell, etc., forthcoming. CD.

Manson, Marilyn and Neil Strauss. The Long Hard Road Out of Hell. New York: ItBooks, 1998. Print.

Marcus, Greil. “Punk.” 1989. Greilmarcus.net. 8 Sep 2014. Web. 16 Jan 2017.

"Marilyn Manson." The Howard Stern Show. CBS, 1998. Television.

“Marilyn Manson Forgets to Release New Album.” Soundblab. 20 Feb 2017. Web. 27 Feb 2017.

Meier, Leslie M. "In Excess? Body Genres, 'Bad Music', and the Judgment of Audiences.” Journal of Popular Music Studies 20.3 (2008): 240-60. Print.

Motley Crüe. “Smokin' In the Boy's Room.” Theatre of Pain. Elektra, 1985. LP.

Muggleton, David. Inside Subculture: The Postmodern Meaning of Style. Oxford: Berg, 2000. Print.

Munro, Scott. “Marilyn Manson Names New Album Heaven Upside Down.” TeamRock 11 May 2017. Web. 16 May 2017.

Pedelty, Mark and Kristine Weglarz. Political Rock. Burlington: Ashgate, 2013. Print.

Richardson, James T., Joel Best and David G. Bromley (eds). Introduction. The Satanism Scare. New York: De Gruyter, 1991. 3-20. Print.

Robinson, Martin. “Album Review: Marilyn Manson The High End of Low.” NME. 19 May 2009. Web. 27 Feb 2017.

Thornton, Sarah. Club Cultures: Music, Media and Subcultural Capital. Cambridge: Polity, 1995. Print. Turner, Victor. The Forest of Symbols: Aspects of Ndembu Ritual. Ithaca: Cornell UP, 1967. Print. Twisted Sister. “We're Not Gonna Take It.” Stay Hungry. Atlantic, 1984. LP. Wilson, Scott. Great Satan's Rage: American Negativity and Rap/Metal in the Age of Supercapitalism. Manchester: Manchester UP, 2008. Print. 
Wright, Robert. “'I'll Sell You Suicide': Pop Music and Moral Panic in the Age of Marilyn Manson." Popular Music 19 (2000): 365-85. Print.

\section{NOTES}

i. A very early draft of this paper was presented at the Radical Americas symposium at University College London in 2015. I thank the organizers and participants for their excellent and helpful feedback.

ii. "Get Your Gunn," one of the album's singles, is a reflection on the murder of OB/GYN doctor David Gunn by a pro-life activist in 1993. The lyrics criticize "your righteous hand" and "pseudomorals," with Manson concluding that these "don't mean a fuck to me."

iii. According to Wright (2000), Klebold and Harris disliked Manson's music. Wright argues that claims that they "followed Marilyn Manson" (381) are therefore unfounded.

iv. Contrary to Manson, Varg Vikerness and Gaahl have both been sentenced for violent crimes, in Vikerness's case for the murder of fellow black metal musician Øystein "Euronymous" Aarseth in 1993.

v. See, for example, Pedelty and Weglarz's work on "political rock," and Gracyk's analysis of rock music and identity politics. While these texts do not use the term transgression explicitly, they do explore the idea that rock music's political power lies in its ability to cross limits, or in Pedelty and Weglarz's words, to "bring people together to form more effective political communities" (xii).

vi. I do not claim that Manson's music solely appeals to adolescents-when attending a concert in 2012 I encountered a range of age groups. It is also feasible that many fans who were adolescents during the 1990s still listen to his music and go to his concerts, even though they are have now progressed into adulthood. While the continued appeal of Manson's music to older age groups could be classified as nostalgia, Manson already had adult fans during earlier stages of his career, and interpreting him as a primarily adolescent artist would be an oversimplification.

vii. Manson made this statement in Bowling for Columbine, using it to argue that his social influence as a rock star is limited in comparison to that of the US President.

viii. In The Forest of Symbols Victor Turner offers an in-depth exploration of the connections between liminality and adolescence, arguing that rites-de-passage occur in a liminal space where adolescents can be transformed into adults: "The first phase of separation compromises symbolic behavior signifying the detachment of the individual or group either from an earlier fixed point in the social structure or a set of cultural conditions (a 'state'); during the intervening liminal period, the state of the ritual subject (the 'passenger') is ambiguous; he passes through a realm that has few or none of the attributes of the past or coming state; in the third phase the passage is consummated" (94).

ix. Early considerations of youth and subcultures as a form of resistance include Hebdige (1979) and Hall and Jefferson (2006), as well as Marcus's (1979) discussion of punk.

x. Other examples of this perspective include Thornton (1995) and Hodkinson (2002).

xi. This concern echoes the concern that youth culture is incapable of functioning as a form of social radicalism altogether, because "its values are not opposed to those of adults but a preparation for them" (Frith 26).

xii. The book's copyrights page states that "some characters are composites," invoking questions as to the factual accuracy of the narrative.

xiii. Richardson et al. (1991) argue that the moral panic regarding Satanist ritual abuse during the 1980 s is an example of how Satanism is a "social construction" (4) which highlights and enforces power relations within American society. 
xiv. Michael Moore's documentary Bowling for Columbine quotes several politicians and activists who blame Manson for the shooting, including an unnamed activist protesting Manson's return to Denver in 2001 with the words: "If Marilyn Manson can walk into our town and promote hate, violence, suicide, death, drug use and Columbine-like behaviour, I can say: not without a fight you can't (sic)!"

xv. One of the best-known policies advocated by the PMRC are the "parental advisory-explicit content" stickers which still adorn the covers of albums deemed inappropriate for minors.

xvi. Marie Fontenot and Chad Harriss offer an in-depth of the PMRC's aims and achievements, concluding that "[s]uccesses in movements like this one are often more symbolic than substantive" (578).

xvii. Martin Robinson of NME, for example, gave The High End of Low a negative review because: "By opening up, he's totally emasculated himself. He sounds defeated, like a man who knows he's been drained of his shock value by Twilight-style mainstream co-option."

xviii. Say10 was originally announced as the album's working title, but in May 2017 Manson confirmed that it had been changed to Heaven Upside Down (TeamRock).

\section{ABSTRACTS}

This article explores how Marilyn Manson functions as a transgressive artist, in order to demonstrate how his persona, music, and music videos cross social, cultural and moral boundaries. In contrast to existing definitions of transgression as a synonym for the breaking of taboos, commonly used in critical interrogations of extreme music, I define transgression as the (re)construction of social order by means of boundary negotiation. I therefore do not read Manson's work as political radicalism or anti-social shock, but as a creative process which (re)constructs the ideologies it appears to attack. The article explores three areas in which this (re)constructive aspect of transgression is most evident. Firstly, I explore how Manson's work functions as a liminal rite-de-passage for adolescents to facilitate a successful transition into adulthood. Secondly, I study how Manson crossed over into the mainstream during the Mechanical Animals-era, and how his relationship with the media affected his negotiation of the mainstream-underground boundary. Finally, I trace how his flirtations with Satanism (re)construct and maintain social order. Manson's transgressive quality, I argue, lies primarily in his ability to expose how American society is (re)constructed and maintained through the crossing and renegotiation of its own limits.

\section{INDEX}

Keywords: Marilyn Manson, transgression, metal music, popular culture, adolescence, MTV, music video, shock rock, Christian Right, Columbine High School massacre 